\title{
Prosto w oczy - JaceK ŁuMiński I ŚląSKi Teatr Tańca (1991-2011)
}

\author{
Alicja IwańsKa \\ alicjaiwanska@op.pl
}

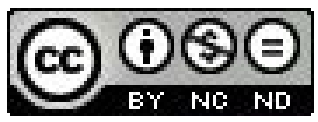

Śląski Teatr Tańca został uznany w roku 1996 przez renomowany „Ballett Internazional/Tanz Aktuell" za najciekawsze europejskie zjawisko w dziedzinie tańca. Swoją działalność artystyczną zainaugurował 4 kwietnia 1992 r. pierwszą premiera, na którą złożyły się dwie prace: Tęsknoty i Ma Guerre a Moi. Jego założycielem, dyrektorem i choreografem jest Jacek Łumiński. Uwierzył on w możliwość powołania do życia teatru według własnej idei i stylu, który wywiódł z polskiej kultury ludowej oraz tradycji Żydów polskich.

\section{JACEK ŁUMIŃSKI: PORTRET}

Początkowo J. Łumiński ${ }^{1}$ kieruje swoje zainteresowania ku muzyce, by w późniejszym okresie zaczęły skłaniać się one w kierunku sztuk scenicznych. Rozwijanie swoich zdolności rozpoczyna od nauki tańca w warszawskiej szkole baletowej w latach 1974-1978. Jednak jej reżim, gorset klasycznego tańca uwierają go na tyle, że po pięciu latach przenosi się do Państwowego Teatru Żydowskiego w Warszawie. Przez sześć lat (1979-1985) uczy się gry aktorskiej i teatru w Państwowym Teatrze Żydowskim, biorąc udział w zajęciach studium aktorskiego oraz występując na scenie teatru w produkcjach artystycznych takich reżyserów, jak: Jakub Rotbaum, Szymon Szurmiej, czy Juliusz Berger. Niezależnie od tego, bierze udział w wernisażach organizowanych przez Towarzystwo Miłośników Sztuk Pięknych. Występuje też w spektaklu Śmierć Dantona w reżyserii Kazimierza Kutza w Teatrze Ateneum oraz w wielu innych spektaklach na terenie całego kraju. Absolwent pedagogiki tańca warszawskiej Akademii Muzycznej im. Fryderyka Chopina (19811985). W latach 1985-1988 tańczy u Conrada Drzewieckiego w Polskim Teatrze Tańca w Poznaniu. Jednocześnie zgłębia technikę tańca modern na kursach zawodowych w Kolonii, Essen i Kopenhadze, jak również w USA: w ośrodku Alvina Aileya, w Juilliard School czy w Bartholin Academy.

W 1988 r. powołuje pierwszy zespół Teatru Tańca Nowego w Olsztynie. Był on wyrazem buntu J. Łumińskiego przeciwko utartym wzorcom i baletowej sitwie. Namawiali go do tego przedsięwzięcia nie tylko przyjaciele z Polskiego Teatru Tańca C. Drzewieckiego, lecz także koledzy ze studiów. Teatr Tańca Nowego przetrwał dwa sezony: jeden w Olsztynie, a drugi w Chorzowie. Pozostało po nim rozczarowanie, co do możliwości tworzenia w Polsce, ale też wielkie doświadczenie życiowe, z którego przyszło mu skorzystać znacznie później, już w Śląskim Teatrze Tańca.

Kiedy City University of New York zaproponował mu objęcie profesury okazało się, że Bytom gotów jest powołać samodzielny zespół tańca. $\mathrm{W}$ podjęciu bytomskiego wyzwania pomogły mu rozmowy z Bożeną Kociołkowska, czołową baleriną polska, która w roku 1991 zorganizowała festiwal tańca w Gdańsku, a następnie z Avi Kaiserem, izraelskim choreografem z Belgii, jednym z najlepszych tancerzy modern w Europie. W październiku 1991 r., pod patronatem miasta Bytomia, J. Łumiński rozpoczyna tworzenie nowej instytucji pod nazwą Śląski Teatr Tańca. Już w styczniu 1992 r. podejmuje pracę z nowym zespołem artystycznym. Śląski Teatr Tańca w swej początkowej fazie

1 Informacje o Jacku Łumińskim pochodzą z następujących źródeł: Katalog XII Międzynarodowej Konferencji Tańca Wspótczesnego i Festiwalu Sztuki Tanecznej, Ślaski Teatr Tańca, Bytom 2005, s. 35-36; Katalog 17 Międzynarodowej Konferencji Tańca Wspótczesnego i Festiwalu Sztuki Tanecznej, Śląski Teatr Tańca, Bytom 2010, s. 46, http://www.stt.art.pl/pl_pl/o_teatrze/jacek_luminski.html, 15.11.2011, http://www.stt.art.pl, 20.11.2011. 
stał się dziewięcioosobowym zespołem, do którego tancerze wybrani zostali przez J. Łumińskiego i A. Kaisera, na drodze audycji ogłoszonych w ogólnopolskich mediach. Premiera okazała się wielkim wydarzeniem. Od tego czasu Śląski Teatr Tańca został uznany za pierwszy polski, zawodowy zespół tańca współczesnego, otwierający nowy etap w historii tańca polskiego.

J. Łumiński zyskał uznanie w wielu kręgach międzynarodowych. Odzwierciedlają to liczne nagrody, granty i stypendia za wybitne osiagnięcia w kształtowaniu unikalnego stylu, techniki i formy teatru tańca. Prowadzi on warsztaty tańca na terenie całego kraju oraz zagranica, m.in. w USA, Kanadzie i Izraelu. Od 2000 r. J. Łumiński pełni funkcję Kuratora przy Contemporary Dance Coproduction Fund (programu Unii Europejskiej). W tym samym roku otrzymał również tytuł profesora Swarthmore College w Filadelfii (USA). Od 2004 r. jest doktorantem Indiana University w Bloomington (USA) na Wydziale Antropologii pod kierunkiem profesor Anyi Peterson Royce. W 2008 r. po uzyskaniu tytułu doktora sztuk teatralnych Państwowej Wyższej Szkoły Teatralnej w Krakowie został dziekanem Wydziału Teatru Tańca tejże uczelni.

Zapytany w 2002 r. przez dziennikarkę „,Rzeczpospolitej” Danutę Lubinę-Cipińską z jakim zamiarem tworzył Śląski Teatr Tańca, J. Łumiński odpowiada: „Zawsze wierzyłem, że taniec współczesny znajdzie u nas odbiorcę, przede wszystkim wśród młodej publiczności. Zależało mi na stworzeniu instytucji, która będzie skupiać zwolenników, łączyć walory artystyczne z edukacyjnymi, a jednocześnie pełnić funkcje usługowe wobec niezależnych twórcó $w^{\prime 2}$. Natomiast w wywiadzie zamieszczonym w „Ultramarynie” w czerwcu 2011 r. czytamy: „Przyjeżdżając na Śląsk moim celem było przede wszystkim połączenie sztuki z tym, co dotyka zwykłych ludzi, z przemianami tożsamościowymi, z zaangażowaniem w środowisko, infrastrukturę, architekturę. Nigdy nie byłem zainteresowany sztuką dla samej siebie - sztuką dla sztuki. Sztuka ma konkretny wymiar ludzki, nie tylko samolubny, i im więcej jest takich działań, tym bardziej ludzie zaczynają się zmieniać. Wydaje mi się, że przez tych 20 lat działalności udało się doprowadzić do tego, że ludzie nam zaufali. To jest najtrudniejsze. Oczywiście można powołać teatr. Ale najtrudniej jest przetrwać" ${ }^{\prime \prime}$. Kiedy J. Łumiński przyjechał do Bytomia w 1991 r. nikt z władz miasta nie wierzył, że uda się stworzyć zespół, który przetrwa dłużej niż rok. Sytuacja powtórzyła się w 1994 r., kiedy Śląski Teatr Tańca zorganizował po raz pierwszy Międzynarodową Konferencję Tańca Współczesnego i Festiwal Sztuki Tanecznej. Radni miasta Bytomia powątpiewali, czy ktokolwiek przyjedzie z zagranicy na ten Festiwal i to w dodatku na Śląsk, a Bytom może się podobać. W dalszej części wywiadu J. Łumiński mówi: „W pewnym momencie w »The Village Voice« ukazała się mapa Europy, na której był zaznaczony Bytom, Berlin, Wiedeń, Paryż... Nikt z nas nie spodziewał się takiego ujęcia sprawy - po prostu robiliśmy to, w co gorąco wierzyliśmy. Sam fakt umiejscowienia Bytomia wśród centrów kulturalnych Europy niesamowicie na mnie i na nas wszystkich w Teatrze zadziałał. (...) W świadomości Amerykanów i Europejczyków Bytom stał się głównym ośrodkiem rozwoju tańca w Polsce..." ${ }^{\prime 4}$. Od tej pory ludzie z całego świata przybywają do Bytomia, chcąc poznać wyjątkowy styl tańca wykreowany przez J. Łumińskiego. Natomiast Śląski Teatr Tańca zyskał sławę głównego propagatora tańca współczesnego w Polsce.

\section{Polska TeChNika TAŃca}

J. Łumiński stworzył nową formę i styl tańca współczesnego w oparciu o bogate tradycje narodowe. Jego styl choreograficzny i tworzony przez niego materiał ruchowy wywodzą się z tra-

2 D. Lubina-Cipińska, Sztuka i warsztaty. Rozmowa z Jackiem Łumińskim, „Rzeczpospolita”, 29.04.2002, http:// www.teatry.art.pl//rozmowy/sztukai.htm, 26.09.2005.

3 J. Łumiński, Taniec jest życiem. Magdalena Podziewska rozmawia z Jackiem Łumińskim, „Ultramaryna”, czerwiec 2011, http://www.ultramaryna.pl/tekst.php?id=907, 15.11.2011.

4 Tamże. 
dycyjnych oraz współczesnych form tanecznych i są ściśle związane z kulturą polską. Podąża on konsekwentnie własną drogą. Źródła jego inspiracji wywodzą się z odmiennych ludowych tradycji Polaków i Żydów. To właśnie w Teatrze Żydowskim, będąc jednym z jego członków pochodzenia nieżydowskiego, zetknął się z kulturą Żydów. Mimo, że z tańcem chasydzkim, żydowskimi rytuałami modlitewnymi i weselnymi obrzędami charakterystycznymi dla przedwojennej Polski zetknął się stosunkowo późno, został wkrótce uznany na arenie międzynarodowej, jako historyk tego, co sam nazywa żydowskim tańcem w Polsce. Styl tańca współczesnego J. Łumińskiego powstał pod wpływem wielu elementów kulturotwórczych, które wyłoniły się w efekcie jego badań (rozpoczętych w 1981 r.) nad tanecznym folklorem Żydów polskich (głównie chasydów) i folklorem polskim (szczególnie muzyką ludową Kurpi i Podhala) odzwierciedlającym polską mentalność, historię oraz położenie geopolityczne. W swojej pracy choreograficznej zaadoptował pewne idee tańca chasydzkiego: nacisk na odpowiednią pracę kręgosłupa i miednicy - co pozwala tancerzom poruszać się z niewiarygodną prędkością w każdym kierunku. Tancerze wdzierają się w przestrzeń sceniczną z ogromną siłą i uderzającą szybkością. Obie te cechy wyrastają z charakterystycznej dla choreografii J. Łumińskiego fascynacji siłą kinetyczną. Autorki Raportu o tańcu wspótczesnym w Polsce tak piszą o technice tańca J. Łumińskiego: „Specyfiką tworzenia ruchu wypracowaną przez Łumińskiego jest analiza sekwencyjna poszczególnych fraz ruchowych, w których dyscyplina ciała i wypracowane mięśnie oraz świadomość rozpoczęcia ruchu i mięśni w nich uczestniczących wraz ze sposobem przekazywania energii - oparte na przykład na zasadach zawieszenia i kontrowania - tworzą dowolność kreowania poszczególnych fraz" ${ }^{\prime \prime}$. Takie podejście do ruchu sprawia, że widz odnosi wrażenie, jakoby tancerze nie podlegali prawu grawitacji.

J. Łumiński zafascynowany folklorem polskim jeździł po Kurpiach, Podlasiu, Lubelszczyźnie, Podhalu i przyglądał się tańcom ludowym. Sam tak o tym mówi: „Z historii wiemy, że wyraziste style i techniki tańca współczesnego powstawały na bazie tradycji. (...) Tak też próbujemy działać w Śląskim Teatrze Tańca: na coś, co jest znane, to znaczy na tradycję współczesnego tańca, nakładam coś, co nie jest znane, ale mi bardzo bliskie, sięgające do moich kulturowych

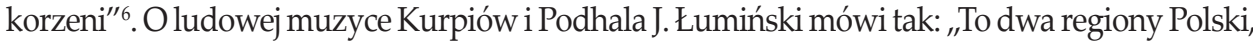
które cieszyły się względną swobodą z racji warunków geograficznych chroniących je przed wpływami z zewnątrz. Na ziemiach tych zachowały się niezwykle ciekawe formy muzyczne i maniery wykonawcze związane z poczuciem wolności i odrębności"7. Taniec współczesny zawsze podkreśla związek ciała tancerza z ziemią. Jednak dla twórców równie ważna jest ekspresja ciała wyzwalającego się ze swoich ograniczeń, odrywającego się od ziemi. Taniec jako modlitwa (funkcjonujący m.in. w tradycji chasydzkiej) lub też połączenie się z siłami nadprzyrodzonymi został włączony do stylu Śląskiego Teatru Tańca. „Gest niedokończony, zawieszony, przerwany jakby w pół i zaczynający się znowu w niespodziewanym miejscu przestrzeni. Taniec, który zaplątał się w spiralę, krą̇̇y, tak jak każe mu rozwichrzona muzyka. Tak można by próbować opisać w największym skrócie rodzaj ruchu, w jaki wprawiają swoje ciała tancerze Śląskiego Teatru Tańca. Ten ruch nie jest naśladowaniem ludowych tańców, ich niezwykle spójnego, ale zatrzaśniętego, nie rozwijającego się już języka. (...) Jeżeli z dawnych tanecznych języków coś zostało, to z chasydzkiego tańca. I znów nie chodzi o cytaty, ale o inspirację dla ge-

5 J. Grabowska, J. Szymajda, Jacek Eumiński i Ślaski Teatr Tańca, [w:] tenże, Raport o tańcu wspótczesnym w Polsce w latach 1989-2009, Kraków - Łódź 2009, s. 21.

6 P. Goźliński, Budzenie do tańca, „Na Przykład. Miesięcznik Kulturalny” 1998, nr 9, s. 15.

Tamże. 
stów własnych nie podpatrzonych, ale wydobytych z własnych ciał i własnych doświadczeń"8. Nie ma tu miejsca na improwizację.

To, co charakteryzuje choreografie J. Łumińskiego, to synkretyzm. „W wypadku Łumińskiego polega on przede wszystkim na jednoczesnym spojrzeniu przed siebie i spoglądaniu za ramię. Łączeniu odległych muzycznych i tanecznych światów" ${ }^{\prime \prime}$.

Śląski Teatr Tańca pokazał oryginalne podejście do sztuki tańca, które wywiódł z kultury ludowej. Jednak tradycja ludowa i taniec ludowy nie są wykorzystywane przez J. Łumińskiego w swych kanonicznych, czy tym bardziej przetworzonych formach. Stanowią raczej pole odniesień dla poszukiwań artystycznych, których celem jest stworzenie polskiego stylu tańca współczesnego.

Oprócz głównego źródła inspiracji, jakimi dla zespołu i J. Łumińskiego są obrzędy, elementy ekstatyczne oraz ludowe struktury muzyczne - stanowiące podstawę stylu Śląskiego Teatru Tańca, ale również decydujące o technice tancerzy - choreograf odwołuje się do dwóch nurtów współczesnej sztuki tańca: do niemieckiego ekspresjonizmu, a właściwie neoekspresjonistycznego teatru tańca oraz amerykańskiego modern dance. J. Łumiński świadomie korzysta z tradycji. Można więc w ogólnym skrócie stwierdzić, iż nowatorski styl tańca współczesnego Śląskiego Teatru Tańca ukształtował się z jednej strony pod wpływem studiów nad metodami pracy takich mistrzów modern dance, jak: Martha Graham, Anna Skolow, czy Jose Limon; z drugiej strony zaś w oparciu o rodzimą tradycję. Nie bez wpływu na styl tańca stworzony przez J. Łumińskiego miała twórczość C. Drzewieckiego ${ }^{10}$. „Mieszanina żywiołowości, wirtuozerii i elegancji dostrzegalna w pracach artystycznych Łumińskiego staje się wyrazem rodzimego środowiska. (...) Nie ma wątpliwości, że choreografie Łumińskiego odzwierciedlają zarazem jego wiedzę o polskiej historii tańca, polskim i żydowskim folklorze, społeczną i duchową rzeczywistość współczesnej Polski oraz jego dogłębną znajomość europejskiego i amerykańskiego tańca współczesnego. Najbardziej uderzający jest fakt, że dzieła Łumińskiego są prawdziwym teatrem tańca. (...) Łumiński zdefiniował i wykrystalizował unikatowy, wysoce ekspresyjny język choreograficzny i teatralny, którego nie sposób znaleźć gdziekolwiek indziej"11. J. Łumiński w swoich pracach w równym stopniu nawiązuje do tradycji wielkich polskich reżyserów/aktorów takich, jak Jerzy Grotowski, Józef Szajna, Tadeusz Kantor, Henryk Tomaszewskich, których teatr inspirowany był ruchem i obrazem, jak również do twórczości choreograficznej C. Drzewieckiego, czy Poli Nireńskiej. Jednym z najważniejszych aspektów jego twórczej działalności jest odbudowanie związków pomiędzy współczesnym polskim teatrem tańca, a jego przedwojenną historią usilnie skrywaną.

W wywiadzie, przeprowadzonym przez Marka Skoczę, tak w skrócie definiuje J. Łumiński swoją metodę tańca: „To cielesne podejście poznawania świata, zbliżone do idei, jakie można spotkać w kulturach pozaeuropejskich, w których rozdział pomiędzy umysłem a ciałem nie nastąpił. Ale wszystko to czynione jest zgodnie z założeniami stworzonymi na bazie polskiej kultury, głównie Kurpiów, Podhala i polskich Żydów, acz nie tylko. W mojej metodzie te wszystkie elementy wzajemnie przenikają się ${ }^{\prime \prime 12}$. Z kultury Podhala czerpie ze zjawiska apokopy (zanikanie głosu na końcu czy na początku wyrazu), intryguje go tempo rubato, kwestia zmiennego metrum oraz wpływu

8 Tamże.

9 Tamże.

10 C. Drzewiecki rozpoczął pracę ze Śląskim Teatrem Tańca w 1998 r. Przygotował spektakl Oczekiwanie do muzyki Pawła Szymańskiego. Premiera spektaklu odbyła się dnia 15 V 1998 r.

11 A. J. Kuharski, Cztery wymiary Ślqskiego Teatru Tańca, [w:] K. Furmaniuk, R. Kuśnierz, J. Łumiński (oprac.), Ślqski Teatr Tańca 1992-2002. Wydanie jubileuszowe Śląskiego Teatru Tańca, Bytom [2002], s. 13-14.

12 M. Skocza, Metoda Łumińskiego. Wywiad z J. Łumińskim, „Śląsk” 10.03.2011, nr 2, http://www.teatry.art.pl/n/czytaj/27531, 20.11.2011. 
sposobu muzykowania na taniec. Interesuje go również sposób gromadzenia w ciele energii oraz uruchamiania jej, który występuje w silnym gardłowym śpiewaniu, zarówno górali (helokanie), jak Kurpiów. Natomiast z kultury chasydzkiej zaczerpnął podział ciała na górną i dolna, z których każda wykonuje inne rytmiczne, niezależne, ale wzajemnie na siebie oddziałujące ruchy. Najistotniejszym jednak elementem metody J. Łumińskiego jest cielesność, ponieważ, jak zauważa jej twórca „poprzez cielesne działanie człowiek bowiem wchodzi na inny poziom myślenia”"13.

Wielu krytyków i teoretyków zajmujących się problematyką teatru tańca zwraca uwagę na sposób prezentowania cielesności na scenie. Anna Królica, autorka tekstu poświęconego funkcjonowaniu i prezentowaniu ciała w polskich spektaklach tanecznych uważa, że to właśnie na lata siedemdziesiąte XX w. przypada wielki zwrot ku ciału, przede wszystkim w praktyce teatralnej. Natomiast polska scena taneczna jest dopiero na początku kształtowania się estetyki tańca współczesnego, jeśliby nie liczyć tradycji tańca niebaletowego (Ausdruckstanz) w okresie międzywojnia. Zdaniem autorki, polskie spektakle taneczne, które powstały w ostatnim dwudziestoleciu, zdecydowanie eksponują poruszające się, tańczące ciało funkcjonujące jako znak, a cielesność nie stanowi w nich tematu samego w sobie. Jedną z przyczyn takiego posługiwania się nim jest, według A. Królicy, ustawienie w centrum koncepcji choreograficznej przedstawienia opowieści zamiast fizycznej obecności wykonawców. W odniesieniu do prac choreograficznych Sląskiego Teatru Tańca autorka uważa, że: ciała tancerzy i tancerek przede wszystkim z pierwszych składów zespołu były świetnie przygotowane pod względem technicznym, „zgodnie z zasadą »ciała niewiarygodnego « typowego dla technik wirtuozerii, (...) czyli ciało wysportowane, silne i umięśnione ${ }^{\prime \prime 14}$. W choreografiach często pojawiają się elementy o charakterze wyczynowym (wspinanie się po linach, chodzenie po wysokich i wąskich konstrukcjach, zwisy czy salta). Eksponuje się nade wszystko sprawność ciał i ich odporność na wysiłek. Tancerze Śląskiego Teatru Tańca prezentują na scenie ciała anonimowe. Jest to efekt stosowania choreografii w obrębie grupy, która charakteryzuje się unifikacją pracy ciała, a ta wycisza specyfikę i charakterystyczność gestów. „W układach Łumińskiego mało jest miejsca na eksplorowanie sfery prywatności tancerzy czy poszukiwanie autentyczności w pracy nad ciałem i jego reakcjami. W ramach konwencji tańca współczesnego, inaczej niż w balecie, dopuszcza się głośne oddychanie, charakterystyczny przyspieszony oddech, ale na tym koniec »prawdy ciała«. (...) W żadnym też przedstawieniu ciało nie było tematyzowane ani poddawane laboratoryjnemu oglądowi"15. Fizyczność we współczesnym europejskim teatrze tańca kojarzona jest nie tylko z wyglądem zewnętrznym ciała oraz jego sprawnością fizyczna, ale także z seksualnością. Jak zauważa A. Królica, J. Łumiński w swoich pracach choreograficznych unika erotyki, „a jeśli już się ona pojawia - to zawsze ubrana w kostium teatralności. Podobnie jak w balecie, charakteryzuje ją umowność (...."16.

\section{ŚląSKi TeATr Tańca: OD TRAdyCjI do wSPÓłCZESNOŚCI}

Śląski Teatr Tańca jest zespołem autorskim. Autorem większości choreografii jest J. Łumiński. Jednak obok choreografii J. Łumińskiego, w ramach działań Laboratorium Choreograficznego Śląskiego Teatru Tańca, powstały cztery spektakle w choreografii Sylwii Hefczyńskiej-Lewandowskiej, jeden Koriny Kordovej oraz duet Sebastiana Zajkowskiego i Leszka Stanka.

13 Tamże.

14 A. Królica, Ciało tańczace poza cielesnościa, czyli o paradoksach polskiego tańca, [w:] D. Jarząbek, M. Kościelniak, G. Niziołek (red.), 20-lecie. Teatr polski po 1989, Kraków 2010 s. 339.

15 Tamże, s. 340.

16 Tamże, s. 339. 
Zespół współpracował również z tej klasy choreografami i tancerzami-pedagogami, co m.in. A. Kaiser, legendarna A. Sokolow, Melissa Monteros, Mark Haim, Sam Costa, Diane Elshout, Frank Handler, Paul Clayden, Hilke Diemer, Mihai Mihalcea, Idan Cohen oraz legendą polskiego modern dance, C. Drzewieckim. Na scenie Śląskiego Teatru Tańca dokonano również rekonstrukcji choreografii polskiej tancerki i choreografki dwudziestolecia międzywojennego, P. Nireńskiej"

Dla zespołu Śląskiego Teatru Tańca J. Łumiński przygotował ponad dwadzieścia choreografii. Inspiracją do powstania pierwszych spektakli był folklor polski i chasydzki, który stał się podstawą scenicznego języka J. Łumińskiego. Świadczą o tym takie spektakle, jak: Mokosz ${ }^{18} \mathrm{Czy}$ Bjamgwamm ${ }^{19}$. Prasa tak o nich pisała: „Po powrocie z Ameryki, nagłośnionym entuzjastycznymi recenzjami tamtejszej prasy, zespół uznał za stosowne przedstawić swój spektakl śląskiej publiczności. (...) najurodziwszy był chyba Mokosz, którym to nazwaniem w słowiańskiej mitologii określa się »ziemię rodzącą ludzi i pożerającą ich «. Radość istnienia uskrzydlał ruch, przecinający przestrzenie i zdobywający świat, który stopniowo konał w osamotnieniu i w bezsilnym skurczu scalał się z ziemią. (...) Wspaniałe w tym programie są kostiumy, wirujące warstwy spódnic i rozchybotane sukmany chłopskie, zaprojektowane przez Kanadyjkę Madleine Brian. Umie dobierać materię, w tym wypadku żorżetę, do charakteru tańca. To program bardzo polski, motywowany muzyką H. M. Góreckiego oraz nutkami Podhalan i Kurpiów" ${ }^{\prime 20}$. Natomiast o Bjamgwamm ten sam recenzent pisze: „(...) jest spontanicznie wesoły i niezmącony egzystencjalną rozpaczą. Tańce fińskie i lapońskie, połączone z muzyką Podhala i Beskidu Śląskiego wyzwalają żywioły. Włącza się znajome górskie echo »Śląska«, ale wtedy właśnie widać najwyraźniej interpretacyjne różnice w choreografii. Biegunowo różne"21.

Kolejne choreografie J. Łumińskiego sprawiaja, iż wielu krytyków i recenzentów uznaje zespół Śląskiego Teatru Tańca za grupę uprawiającą teatr zmysłowy i poetycki. „W swych spektaklach wzmacnia Łumiński zmysłowy odbiór widza nie tylko swoim tańcem, lecz także elementami klasycznego teatru oraz muzyka, kreującą czas i przestrzeń. Tym samym wpisuje swój teatr $\mathrm{w}$ wielowiekową tradycję teatru poetyckiego"22. Równocześnie jednak grupa pamięta o wrażliwości współczesnego widza, przyzwyczajonego do innych form przekazywania artystycznych treści. Dlatego czasami „Łumiński posługuje się kodem współczesnego odbiorcy telewizyjnych reklam wierząc, że to jedyna droga by do dzisiejszego człowieka trafić. Jednak traktuje ów kod jedynie jako narzędzie w rozmowie sterując odbiorem może jednocześnie, w sposób nieuświadomiony przez widza, przemycać zamierzone przez siebie treści"23.

W przedstawieniach zespołu bytomskiego obecne są także bezpośrednie odniesienia do polskiej rzeczywistości. Pojawiły się one m.in. w spektaklu WK-7024, który opowiada o dziedzictwie PRL-u i narodowych wadach Polaków. J. Łumiński stworzył fascynujący spektakl, wsparty pol-

\footnotetext{
17 Premiera rekonstrukcji choreografii Poli Nireńskiej Pieśn żałobna do muzyki Ernesta Blocha odbyła się na scenie Śląskiego Teatru Tańca 6 XII $1997 \mathrm{r}$.

18 Premiera: 4 VI 1994 r., muzyka: Henryk Mikołaj Górecki, polska muzyka ludowa; kostiumy: M. Brian; Śląski Teatr Tańca w Bytomiu.

19 Premiera: 9 X 1994 r., muzyka: fińska, lapońska, polska muzyka ludowa/Jan Sebastian Bach, Bartłomiej Pękiel; Śląski Teatr Tańca w Bytomiu.

20 (IS), Ale tańcza!!, „Gazeta Opolska”, 3-5.02.1995, nr 25.

21 Tamże.

22 J. Leśnierowska, Na czym polega fenomen Ślaskiego Teatru Tańca na polskiej scenie?, [w:] K. Furmaniuk, R. Kuśnierz, J. Łumiński (oprac.), Ślaski Teatr Tańca 1992-2002, dz. cyt., s. 6.

23 Tamże.

24 Premiera: 30 IV 1998, muzyka: Paweł Szymański, Johann Jeremias du Grain, Kudsi Erguner, Elizabeth Valletti, gruzińska i polska muzyka ludowa; kostiumy: Hanna Nowicka-Rożeń, światło: David Herriget; Śląski Teatr Tańca w Bytomiu.
} 
ską i gruzińską muzyką ludowa, przeplataną współczesnymi brzmieniami. Świat WK-70 składa się z pustej sceny i wydłużonej przeszklonej budowli, przesuwanej podczas spektaklu przez tancerzy. To oni i konstrukcja budują dramatyczne napięcie. U J. Łumińskiego konstrukcja ta symbolizuje gigantyczne anonimowe blokowisko podzielone na betonowe sypialnie. Kobiety i mężczyźni spotykają się tu przelotnie i przypadkowo. Spotkania bywają często brutalne, a czasami czułe. Rzadko kiedy spotkania te odbywają się poza przeszkloną budowla, która chwilami przypomina podglądany z ulicy mieszkalny blok.

Spektakl ten można odczytywać na wiele sposobów, ale jedno nie ulega wątpliwości, że J. Łumińskiemu udało się osiagnąć poprzez ruch, taniec oraz wspaniale współgrającą z nim muzykę, ogromne stężenie emocji, bolesnych wspomnień i refleksji nad kondycją współczesnych Polaków. WK-70 został uznany przez krytyków i widzów za największe osiągnięcie Śląskiego Teatru Tańca oraz polskiego tańca współczesnego ostatniej dekady XX w. W prasie ukazało się wiele recenzji, które podkreślały wyjątkowość tego spektaklu. Sandra Wilk w „Życiu” pisała po premierze: „Zachwyty wzbudził najnowszy spektakl Śląskiego Teatru Tańca WK-70. (...) charakterystyczną cechą jest ponadczasowość i uniwersalność. Wszystko to sprawia, że mamy do czynienia z widowiskiem naprawdę światowej klasy" ${ }^{25}$. W podobnym stylu utrzymana jest recenzja Mirosława Haponiuka: „,W spektaklu WK-70 perfekcja techniczna jego [J. Łumińskiego] tancerzy łączyła się z wyrazistościa, przejrzystość kompozycji z oryginalnością teatralnych pomysłów. Nie mieliśmy wątpliwości, że tancerze Jacka Łumińskiego tańczą o sobie i o nas - dzieciach osiedli z wielkiej płyty. (...) spektakl Śląskiego Teatru Tańca to jedno z najmocniejszych świadectw naszej współczesności, a zarazem świadectwo możliwości sztuki tańca"26. Natomiast Bartosz Kamiński tak pisał o tym spektaklu: „Rzecz jest o Polsce i Polakach, o przekleństwie PRL-u i narodowych wadach, ciemnych siłach, na których był budowany, a które tkwią w nas nadal. Wstrząsające przedstawienie, które można też czytać w sposób uniwersalny, bez odniesień do polskich doświadczeń. Polskości jest w WK-70 co niemiara, począwszy od hipnotycznych kurpiowskich zaśpiewów Apolonii Nowak, aż po sam styl choreograficzny Łumińskiego i technikę jego autorstwa, będącą fuzją najróżniejszych współczesnych technik tanecznych"27. J. Łumiński w swoim przedstawieniu zmierza od konkretu do abstrakcji. Ponad godzinę trzyma widza w napięciu.

Kolejny spektakl J. Łumińskiego Niewinne marzenia u schyłku ${ }^{28}$ opowiada o ludziach końca XX w. i ich kondycji. To przejmująca opowieść o ich słabościach, nadziejach i rozczarowaniach, o miłości, przemocy i samotności. Spektakl ten dotyka spraw ponadczasowych. Unaocznia nasze niepokoje, obawy i problemy ludzi schyłku drugiego tysiąclecia. Ciagle jesteśmy samotni, a rozpaczliwe próby zmiany tego stanu nie prowadzą do niczego. Okazuje się bowiem, iż pomimo upływu czasu, rozwoju cywilizacji człowiek ciągle potrzebuje akceptacji i miłości innych, poczucia bezpieczeństwa.

Niewinne marzenia u schyłku J. Łumińskiego to spektakl z świetnie podkreślającym dramaturgię muzycznym kolażem. Półtoragodzinne widowisko opowiada o młodych ludziach, o relacjach między kobietą i mężczyzna, o ich magnetyzmie, o różnicach obu płci, które tak silnie przyciagaja, o uczuciach, przywiązaniu i miłości, ale też i o biologicznej determinacji natury człowieka. „Zespół Łumińskiego przejmująco pokazuje nam i to, co boli, z czym nie chcielibyśmy wkraczać w XXI wiek

25 S. Wilk, „Życie”, [w:] K. Furmaniuk, R. Kuśnierz, J. Łumiński (oprac.), dz. cyt., s. 66.

26 M. Haponiuk, „Gazeta w Lublinie”, [w:] K. Furmaniuk, R. Kuśnierz, J. Lumiński (oprac.), dz. cyt., s. 70.

27 B. Kamiński, Taniec doświadczeń. Festiwal Sztuki Tanecznej w Bytomiu, „Życie”, 29.06.1998, s. 9.

28 Premiera: 29 IV 1999; muzyka: Karl Jenkins, Meredith Monk, Paweł Szymański, Hildegard von Bingen, Agathodamon, Eleni Karaindrow, Luz Lasal, Oracle oraz muzyka średniowieczna; Śląski Teatr Tańca w Bytomiu. 
i trzecie tysiąclecie - agresję. Bodaj najdobitniej uwidaczniają ją wojny. Spektakl Łumińskiego boli bardziej, bo pokazuje ów początek wojennego zła w nas samych. (...) Wystarczy iskierka, by zburzyć (jak w spektaklu mur) w sobie ową granicę Dobra i Zła. W tej ruinie trudno wrócić do dobra. Ciężko odzyskać utraconą niewinność, zwłaszcza gdy obojętnieją wszyscy. Finałowa szamotanina tego, »który przejrzał", niezwykle silnym jest dla nas ostrzeżeniem. Piękny i mądry to spektakl”29.

Inspiracją dla J. Łumińskiego do kolejnego spektaklu ${ }^{30}$ była legenda, która mówi, że na końcu tęczy jest ukryty skarb. Tęcza to oczywiście przenośnia. Chodzi przede wszystkim o człowieka, który poszukuje „,skarbu”. „Przeważnie, nawet jeśli się swój skarb odnajdzie, nie jest się w stanie go docenić. Pojawiają się pewne tropy nikczemności” - mówi J. Łumiński. - „Każdy z nas te nikczemności popełnia - większe czy mniejsze. I one właśnie pochłaniają tyle naszej energii, że zapominamy, po co żyjemy. Zapominamy o szukaniu naszego »skarbu «" ${ }^{\prime 31}$.

$\mathrm{Na}$ końcu tęczy to moralitet, w którym taniec stanowi najważniejsza, lecz nie jedyną formę ekspresji. Bardzo ważne są tu i scenografia (wysokie rusztowania), i kostiumy, i rekwizyty, oczywista muzyka i światło oraz - nieoczywiste słowo. Punktem wyjścia jest tu jakby średniowieczna lamentacja. Dusza z ciała uleciała, lecz ociaga się z ostatecznym odejściem z tego świata - skutek niemożności pożegnania się z bliskimi i świadomość konieczności przejścia przez „„zyśćcowe męki", aby móc dostąpić życia wiecznego. Siedmiu tancerzy, siedem dusz dokonuje na scenie publicznego rachunku sumienia i spowiedzi z grzesznych uczynków, aktu skruchy i żalu - doznając dzięki temu łaski oczyszczenia z przewin. Scenografia, którą stanowi wysokie rusztowanie sugeruje bądź to dziób pasażerskiego statku, dom, nocny klub... Tancerze szybko próbują wspią́ się na rusztowanie, ześlizgują się z niego, podejmują kolejne próby - wszystko na próżno. Dorota Mrówka tak pisała o tym spektaklu: „Najnowszy spektakl Jacka Łumińskiego jest metaforą ludzkiego losu, poszukiwania przez każdego z nas, tego co w życiu najważniejsze. (...) Można doszukiwać się w przedstawieniu wątków miłości - także tej trudnej i niespełnionej, nostalgii za przeszłościa, potrzeby akceptacji, samotności, rozstań i powrotów"32. Ogromna konstrukcja ustawiona na środku sceny, jedyny element scenograficzny, odgrywa w przedstawieniu znaczącą rolę. Tancerze poza powierzchnią sceny mają także do wykorzystania kilka poziomów konstrukcji. To pozwala na misterne rozplanowanie i zagospodarowanie przestrzeni, $\mathrm{w}$ którą wpisane zostają choreograficzne układy. Spektakl jest niezwykle dynamiczny poprzez ciagłe zmiany rytmu i tempa oraz równoległe prowadzenie scenicznych zdarzeń. Muzyka zmienia się nagle. Słyszymy przedwojenne tango, rzewne ludowe pieśni, a także współczesną muzykę poważną. Wraz z muzyką zmienia się nastrój, światło, układy, a także treść poszczególnych scen.

W programie spektaklu Prosto $w$ oczy $y^{33}$ czytamy: „Po raz kolejny próbujemy podjąć dyskurs o uczciwości i poszukiwaniu korzeni łączących nas z naturą. Prosto w oczy podkreśla wagę relacji międzyludzkich. Zbyt często zapominamy o innych ludziach, którzy mają swoje potrzeby, tęsknoty, poglądy, zwyczaje, itd. Powiedzenie, że »na dnie oczu czai się dusza« jest prawdą uznawaną przez wiele różnorodnych kultur na całym świecie. Prawdą wyczuwaną intuicyjne, odsłaniającą naszą osobistą nostalgię oraz związek z niedefiniowanym, ale bliskim światem...

29 M. Skocza, To, co najlepsze - nasze!, „Dziennik Zachodni”, 7.07.1999, s. 7.

30 Na końcu tęczy, premiera: 26 V 2001 r.; muzyka: Paweł Szymański, rosyjski i polski folklor, Georg Friedrich Heandel, Kimmo Pohjonen, Richard Barrett, Paul, Obermayer; scenografia: Jacek Łumiński; kostiumy: Hanna Nowicka-Rożeń; Śląski Teatr Tańca w Bytomiu.

31 A. Dąb, Wierzę w cuda. Rozmowa z Jackiem Łumińskim, „Gazeta Wyborcza”, 25.05.2001, s. 10.

32 D. Mrówka, Skarb nieodnaleziony, „Gazeta Wyborcza”, 6.06.2001, s. 9.

33 Premiera: 7 VI 2002 r.; muzyka: Stepanida, Huun-Huurtu \& Bułgarski Chór Żeński, Evelyn Glennie, Paweł Szymański, polskie pieśni ludowe, Brthomastates; scenografia: Jacek Łumiński, video: Violetta Rotter-Kozera, kostiumy: Magdalena Duda. 
Sytuacja ekonomiczna, zamieszania informacyjne, dewaluacja wartości powoduja, że coraz częściej szukamy niekonwencjonalnych sposobów uzdrawiania duszy. Szukamy miłości, śnimy o niej, marzymy o lepszym życiu..." ${ }^{\prime 34}$.

Prosto w oczy to spektakl opowiadający o zagubieniu i próbie odbudowania podstawowych więzi międzyludzkich. Na scenie widzimy młodych, zagubionych w codziennym życiu ludzi. Bohaterowie, $\mathrm{w}$ poszukiwaniu tego, co w naszym skomplikowanym i chaotycznym świecie pozostało jeszcze prawdziwe - najczystszych uczuć, penetrują najgłębsze pokłady ludzkiej natury. Praca video ${ }^{35}$, będąca swoistym przedłużeniem żywych postaci wykreowanych ruchami i głosem tancerzy, jest istotnym elementem zamysłu choreografa.

Prosto w oczy odniosło za oceanem poważny sukces. Tak pisał o nim „The New York Times": „W czasach, gdy nawet najpoważniejsi twórcy za cel stawiają sobie zabawić publiczność, Jacek Łumiński ze swoim Śląskim Teatrem Tańca - zespołem tańca współczesnego z polskiego Bytomia, nie schlebia bynajmniej popularnym gustom. Jak zawsze w swojej pracy, Jacek Łumiński, pozostaje bezkompromisowy $\mathrm{w}$ konsekwentnym odrzucaniu konwencjonalnych rozwiązań. (...) Spektakl jest trudny, wypełniony sekwencjami, których nie sposób postrzegać inaczej, jak surrealistycznie. Obrazy są enigmatyczne, lecz poprzez wysoce fizyczny ruch, docierają głęboko do emocjonalnych stanów" ${ }^{\prime \prime 36}$.

La. La Land ${ }^{37}$ inspirowany był przez Immersive Technologies, a konkretnie ideą tzw. wyobrażonego społeczeństwa, którą po raz pierwszy sformułował Benedict Anderson ${ }^{38}$. W spektaklu poruszony został temat silnego wpływu techniki na rzeczywistość całego społeczeństwa oraz tego, jak wirtualny świat wystawia na próbę zmysłowe doświadczenia i ludzkie emocje. $L a$, $L a$ Land wraca do dyskusji o tym, czy to, co widzimy, jest prawdziwe. „Spektakl La, La Land porusza ważne problemy współczesnego świata. Cukierkowa kolorowa, kwiatowa scenografia oddaje estetykę wirtualnej rzeczywistości, tworzonej z przesadną dbałością o szczegóły, obciążonej pragnieniem bycia bardziej rzeczywistą niż rzeczywistość. Ekspresyjny taniec wykonywany do rytmu kakofonicznej muzyki ukazał różnorodne stosunki społeczne, różne potrzeby ludzi, chaos ${ }^{\prime \prime 39}$. Natomiast Alan Misiewicz tak pisał o tej choreografii: „Siedmioro tancerzy poddawanych jest powolnemu upodobnianiu się do siebie. Z czasem jednak wszystko zatraca swoją ciagłość. Powoli świat zaczyna się odrealniać. Rzeczywistość nadal jest piękna, ale już nie taka idealna. Pluszowe kwiatki rosnące w małych pluszowych doniczkach tworzą urzekający kontrast dla powagi problemu zatracania się w wirtualnej rzeczywistości. Kradzież tożsamości dokonuje się powoli. Twarze tancerzy nakładają się na siebie i przenikaja, a muzyka staje się narkotyczna, wprawia w trans, jakby nie było pocieszenia, drogi powrotnej, ucieczki" ${ }^{\prime 40}$.

Już z tej pobieżnej charakterystyki dorobku choreograficznego J. Łumińskiego dla zespołu Śląskiego Teatru Tańca, dokonanej na kilku tylko przykładach, wyraźnie widać, że przedstawienia te rzadko osadzone są w tradycji literackiej, raczej odwołują się do rzeczywistości społecznej. Choreograf stara się przede wszystkim przenosić na scenę zaobserwowane relacje międzyludzkie. Jed-

34 Program Prosto w oczy, Śląski Teatr Tańca, Bytom 22.06.2003.

${ }_{35}$ Prezentacja kalejdoskopu zwykłych ludzi w ich codziennych sytuacji, na tle panoramy krajobrazu Górnego Ślaska.

36 A. Kisselgoff, „The New York Thimes”, [w:] K. Furmaniuk, R. Kuśnierz, J. Łumiński (oprac.), dz. cyt., s. 34.

37 Premiera: 9 IV 2010; muzyka: Zbigniew Karkowski, Stefan Betke (Pole), Panasonic, Aleksander Lasoń; wizualizacje: Aleksander Joachimiak; światła: Łukasz Opieczonek.

${ }_{38}$ B. Anderson, Wspólnoty wyobrażeniowe. Rozważania o źródlach i rozprzestrzenianiu się nacjonalizmu, Warszawa-Kraków 1997.

${ }_{39}$ M. Mikurt, „Fabryka Tańca”, http://www.stt.art.pl/pl pl/spektakle_11_12/la_la_land.html, 20.11.2011.

40 A. Misiewicz, „,Gazeta Wyborcza”, http://www.stt.art.pl/pl_pl/spektakle_11_12/la_la_land.html, 20.11.2011. 
nak najnowsze choreografie J. Łumińskiego nie są już tak interesujące i oryginalne, jak te z początku działalności zespołu. W prasie polskiej pojawiają się coraz częściej i krytyczne opinie dotyczące prac choreograficznych J. Łumińskiego i Śląskiego Teatru Tańca powstałych po 2000 r. Pisze o tym, m.in. Julia Hoczyk w miesięczniku „Kultura Enter”: „Grupa Śląskiego Teatru Tańca, tworząca niegdyś ciekawe i nowatorskie spektakle, utknęła w miejscu. Przedstawienia, z początku udane odzwierciedlające historię kraju i regionu (np. Niewinne marzenia u schyłku, WK-70), następnie jeszcze mniej dosłowne i fabularyzowane, bardziej poetyckie, silnie oddziałujące intensywnością ruchu i sugestywnością scenicznych obrazów (między innymi Na końcu tęczy czy Środek ciężkości - jedna z pierwszych propozycji Atelier w choreografii Leszka Stanka i Sebastiana Zajkowskiego), powróciły do punktu wyjścia. Poszukiwania nie zaskakują. Znakomita technika (...) budzi podziw, lecz nuży, gdy zaczyna funkcjonować niczym sztuka dla sztuki (jak stało się między innymi w Reakcji chemicznej i Die Künst der Fuge). Spektakle niebezpiecznie ciążą w stronę fabuły i opowieści, co nie byłoby może wadą w przypadku dzieł intrygujących, budzących zaciekawienie. Niestety - są przewidywalne, zarówno w warstwie intelektualnej, jak i ruchowej"41. Autorka uważa, iż znacznie ciekawsze wydają się jej kameralne propozycje, które w ramach Laboratorium Śląskiego Teatru Tańca przygotowały solistki grupy, S. Hefczyńska-Lewandowska i K. Kordova. Poprzez swoją działalność Laboratorium ${ }^{42}$ może ewoluować w stronę twórczych poszukiwań oraz przełamania form, co stworzyłoby pewną szansę dla zespołu. Wśród ostatnich spektakli Śląskiego Teatru Tańca, według J. Hoczyk, trudno zauważyć bowiem jakieś znaczące dokonania.

\section{Dziatalność edukacyjna Śląskiego Teatru Tańca}

Przez dwadzieścia lat swej działalności Śląski Teatr Tańca w Bytomiu zaangażował się $\mathrm{w}$ wiele projektów społecznych i artystycznych ${ }^{43}$. Ważnym elementem działalności teatru są inicjatywy na rzecz lokalnej społeczności. Szczególnym terenem związanym z działalnością społeczną Śląskiego Teatru Tańca jest dzielnica Bobrek. To postindustrialny obszar objęty strukturalnym bezrobociem, niegdyś miejsce wielu zakładów przemysłu ciężkiego. Obecnie w dzielnicy realizowany jest projekt Bobrek Dance ze środków Ministra Kultury i Dziedzictwa Narodowego, a adresowany do młodzieży ze środowisk zagrożonych. W poprzednich latach Śląski Teatr Tańca przeprowadzał również inne działania na terenie dzielnicy, zakładając młodzieżowy zespół Młodzi Gniewni (2005) czy angażując do współpracy folklorystyczną grupę Piekarskie Klachule (2005). Tego rodzaju działania aktywizują środowiska marginalizowane. Wśród licznych projektów społecznych Śląski Teatr Tańca organizuje warsztaty tańca integracyjnego dla osób niepełnosprawnych ruchowo (m.in. poruszających się na wózkach inwalidzkich i po amputacji). Inną formą tanecznej aktywności osób sprawnych inaczej jest działalność Integracyjnego Teatru Tańca Kierunek oraz zespołu Mały Kierunek. Wymienić należy również zajęcia i warsztaty z udzia-

\footnotetext{
${ }^{41}$ J. Hoczyk, Bytom - zmierzch legendy, [w:] tejże, Teatr tańca AD 2008. Nadzieje i kontynuacje, „Kultura Enter. Miesięcznik Wymiany Idei", http://kulturaenter.nazwa.pl/0/01t4.html, 12.04.2010.

${ }^{42}$ Informacje o działalności Laboratorium Choreograficznego Śląskiego Teatru Tańca zamieszczone są również w następujących źródłach: Katalog 17 Międzynarodowej Konferencji Tańca Współczesnego i Festiwalu Sztuki Tanecznej, Śląski Teatr Tańca, Bytom 2010, s. 11-12, W. Mrozek, Raport o stanie tańca w województwie ślaskim, Instytut Muzyki i Tańca 2011, s. 5 (dostępność raportu na stronach internetowych: http://www.kongrestanca.pl/pl/materialy, 22.04.2011, http://www. kongrestanca.pl/uploads/files/11_raport-slask-pdf.pdf, 22.04.2011), http://www.stt.art.pl, 20.11.2011.

${ }_{43}$ Informacje o działalności artystyczno-edukacyjnej Śląskiego Teatru Tańca pochodzą z następujących źródeł: Katalog XII Międzynarodowej Konferencji..., dz. cyt., s. 19-20, W. Mrozek, Raport o stanie tańca..., dz. cyt., s. 5-6, http://www. stt.art.pl/pl_pl/o_teatrze/nota.html, 15.10.2011, http://www.stt.art.pl/pl_pl/o_teatrze/organizacja.html, 15.10.2011, http:// www.stt.art.pl, 20.11.2011.
} 
łem dzieci z bytomskich domów dziecka, mieszkańców Domów Opieki Społecznej, seniorów, dzieci z najbiedniejszych terenów Śląska, warsztaty integracyjne, terapii przez ruch skierowane do osób z zaburzeniami psychicznymi, niepełnosprawnymi fizycznie i niewidomych, projekty społeczne dla dzieci z porażeniem mózgowym oraz projekt Bliżej sztuki - program edukacyjny dla młodzieży zagrożonej ${ }^{44}$.

Śląski Teatr Tańca współpracuje z wieloma instytucjami rządowymi i pozarządowymi na całym świecie przy realizacji projektów społecznych, artystycznych i edukacyjnych.

Poza licznymi projektami społecznymi i artystycznymi Śląski Teatr Tańca realizuje programy edukacyjne. W ramach działalności edukacyjnej teatru prowadzone są od 1992 r. comiesięczne, regularne warsztaty tańca (krajowe i międzynarodowe) dla amatorów, tancerzy i choreografów. Dzięki staraniom J. Łumińskiego i Śląskiego Teatru Tańca utworzono pierwszy w Polsce wydział tańca współczesnego w Ogólnokształcącej Szkole Baletowej im. Ludomira Różyckiego w Bytomiu oraz zorganizowano w 1995 r. Warsztaty Edukacyjne dla Nauczycieli Tańca i Liderów Środowiska. W październiku 2005 r. Śląski Teatr Tańca rozpoczął realizację projektu Wyższej Szkoły Sztuk Performatywnych, stanowiącego podwaliny pierwszej w Polsce szkoły kształcącej tancerzy tańca współczesnego na poziomie szkoły wyższej. W tym samym miesiącu odbył się nabór do programu pilotażowego, którego celem było sprawdzenie struktur organizacyjnych i treści programowych Szkoły. Dzięki wsparciu europejskiego programu Leonardo da Vinci ponad dwudziestu uczestników brało przez rok udział w regularnych sesjach zajęć teoretycznych i praktycznych prowadzonych przez specjalistów z Polski i z Unii Europejskiej. Obok J. Łumińskiego i S. Hefczyńskiej-Lewandowskiej zajęcia prowadzili m.in. H. Diemer (Rotterdamse Dansakademie), Katja Schneider (Uniwersytet w Monachium) czy Roman Arndt (Folkwang Hochschule, Essen). Równolegle trwały prace nad otwarciem w Bytomiu biblioteki tanecznej, gromadzącej fachową literaturę. 22 września 2006 r. J. Łumiński oraz Jerzy Stuhr - ówczesny rektor Państwowej Wyższej Szkoły Teatralnej im. Ludwika Solskiego w Krakowie - ogłosili zamiar otwarcia w krakowskiej uczelni teatralnej nowej specjalizacji: aktor teatru tańca. Od roku akademickiego 2007/2008 specjalizacja ta powołana została w ramach Wydziału Aktorskiego i prowadzona była w Krakowie. Po roku przekształciła się w odrębną jednostkę organizacyjną - Wydział Teatru Tańca, z siedzibą w Bytomiu (jest to zamiejscowy Wydział Aktorski krakowskiej Państwowej Wyższej Szkoły Teatralnej). Dziekanem nowo powołanego wydziału jest dr J. Łumiński, prodziekanem - dr S. Hefczyńska-Lewandowska. Program łączy gruntowny trening technik tanecznych z kształceniem aktorskim, prowadzonym przez pedagogów krakowskiej uczelni teatralnej. Spośród wykładowców przedmiotów tanecznych należy wymienić m.in.: dr Barbarę Sier-Janik, Evę Lackova, dra Janusza Skubaczkowskiego, George’a Blaschke, Joe Altera. Szkoła kształci krytyków, wykonawców i twórców tańca ${ }^{45}$.

Z edukacyjnego punktu widzenia ważnym aspektem działalności Śląskiego Teatru Tańca jest także organizacja obszernego bloku warsztatowego podczas Międzynarodowej Konferencji Tańca Współczesnego i Festiwalu Sztuki Tanecznej. To najbardziej elitarna impreza organizowana od 1994 r. przez teatr, jedna z największych i najpoważniejszych imprez tego typu w Europie. Co roku, od siedemnastu lat, na przełomie czerwca i lipca, przez dwa tygodnie tancerze z całego świata wystawiają swoje spektakle i prowadzą intensywne warsztaty tańca w Bytomiu. Obok

44 Informacje pochodzą z następujących źródeł: W. Mrozek, Raport o stanie tańca..., dz. cyt., s.6, Katalog XII Międzynarodowej Konferencji..., dz. cyt., s. 52.

45 Informacje pochodzą z następujących źródeł: Katalog 17 Międzynarodowej Konferencji..., dz. cyt., s. 15, W. Mrozek, Raport o stanie tańca..., dz. cyt., s. 7, http://www.pwst.krakow.pl/?strona=2\&lp=3, 15.10.2011. 
warsztatów rozlicznych technik tanecznych odbywają się warsztaty pisania o tańcu dla krytyków i historyków tańca, warsztaty fotografii tanecznej czy warsztaty menedżerów sztuki ${ }^{46}$.

\section{Fenomen Śląskiego Teatru Tańca}

Śląski Teatr Tańca powstał w czasach niełatwych dla kultury ${ }^{47}$, tuż po ustrojowej i gospodarczej transformacji, zapowiadając nowy okres w dziejach tańca w Polsce. Jest on dziś bez wątpienia jednym z ważniejszych ośrodków sztuki tańca współczesnego w naszym kraju. J. Leśnierowska zastanawiając się, na czym polega fenomen Śląskiego Teatru Tańca, pisze: „(...) fenomen zespołu Łumińskiego polega w równym stopniu na tańcu, jak i na samym TEATRZE. (...) Teatr Łumińskiego jest bowiem teatrem na wskroś antropocentrycznym. Tematami przedstawień są przede wszystkim ludzie - ich odwieczne zmagania ze światem i sobą samym. (...) W rzeczywistości miejscem akcji wszystkich spektakli jest człowiecze wnętrze - arena zapasów duszy z siłami większymi od niej. (...) Owa walka właśnie, dla której taniec jest najlepszym środkiem wyrazu, wydaje się dla choreografa podstawowym sensem życia, wspólnym wszystkim ludziom niezależnie od czasu. W ten sposób, dając wyraz wierze w człowieka i moc jego duszy, opowiada się Łumiński po stronie humanizmu" ${ }^{\prime \prime 8}$. Zdaniem autorki, to widz jest najważniejszy dla J. Łumińskiego, a sam spektakl, który stanowi akt komunikacji, staje się okazją do przekazania ważnych treści, oddziaływania na zmysły odbiorcy, pobudzenia konkretnych reakcji, a także wymiany doświadczeń. To właśnie teatr tańca, wobec kryzysu teatru słowa, przyjmuje dziś zadanie zgłębiania rzeczywistości, podstawiania publiczności lustra, czy też pokazywania jej drogi do wnętrza samej siebie.

Natomiast Roman Pawłowski z „Gazety Wyborczej” tak uzasadniał nominację J. Łumińskiego do Paszportów „Polityki” w 1997 r.: „Łumiński podjął się pracy S y z y f a - chce uprawiać taniec nowoczesny w kraju, w którym rozwój nowoczesnej choreografii został na pół wieku zamrożony przez balet klasyczny. Osiągnięciem Łumińskiego jest jego oryginalny styl choreograficzny, czerpiący z polskiego i żydowskiego folkloru, rozpoznawany na świecie jako polski styl tańca" ${ }^{\prime 9}$. Styl ów ma swoistą głębię i niepowtarzalne piękno. Nie bez powodu wielkim uznaniem cieszy się Sląski Teatr Tańca poza granicami kraju.

Prestiżowy „Dance Magazine” wymienił J. Łumińskiego jako jednego z trzech choreografów na świecie, rokujących największe nadzieje. J. Łumiński udowodnił, że jest jednym z najoryginalniejszych choreografów tańca współczesnego, a jego technika pozwala tworzyć sugestywne układy i brawurowe sceny.

Zapytany przez M. Skoczę, co z minionego dwudziestolecia uważa za największy sukces swój i Śląskiego Teatru Tańca, odpowiada: „Po pierwsze: istnienie teatru na arenie międzynarodowej; silne i mocne. Jesteśmy rozpoznawalni. Ważnym jest dla nas i to, że wiedzą o tym również pracownicy wszelkich polskich instytucji powołanych do promocji polskiej kultury

${ }^{46}$ Informacje o Międzynarodowej Konferencji Tańca Współczesnego i Festiwalu Sztuki Tanecznej znaleźć można m.in.: W. Mrozek, Raport o stanie tańca...,dz. cyt., s. 8, http://www.stt.art.pl, 20.11.2011.

${ }^{47}$ Początek lat dziewięćdziesiątych XX w. to okres likwidacji wielu instytucji kultury, ale także zniesienie cenzury i monopolu państwa, decentralizacja i komercjalizacja kultury. To czas kształtowania się nowych zasad funkcjonowania placówek kulturalnych. W warunkach niedomagającego mecenatu państwowego i samorządowego na kształt kultury artystycznej coraz większy wpływ wywiera rynek. To on dyktuje warunki, wybiera, selekcjonuje. Nieskory jest do inwestowania w promocję, kształtowanie gustów, edukację kulturalną. Poddany prawom ekonomii znacznie częściej wybiera komercję aniżeli przedsięwzięcia ambitne i wysokich lotów. Decydujące samodzielnie o priorytetach gminy w różny sposób traktują sprawy kultury. A nakłady na kulturę w budżetach gmin w owym czasie były niewielkie, bądź ich brakowało.

48 J. Leśnierowska, Na czym polega fenomen Ślaskiego Teatru Tańca na polskiej scenie? [w:] K. Furmaniuk, R. Kuśnierz, J. Łumiński (oprac.), dz. cyt., s. 6-7.

49 M. Skoczyna, Wedlug Eumińskiego, ,Ślassk” 1997, nr 2 (16), s. 69. 
w świecie. (...) Po drugie: zaistnienie teatru w samym Bytomiu, w świadomości jego mieszkańców. Może nie ma ono charakteru masowego, ale jest faktem. Po trzecie: wyrosła na bazie tego, co i tak w Śląskim Teatrze Tańca robimy, szkoła - Wydział Teatru Tańca w Bytomiu Państwowej Wyższej Szkoły Teatralnej im. Ludwika Solskiego w Krakowie. Piękne jest to, że dla tańca współczesnego wychowuje się nowe pokolenie młodzieży, że ci młodzi wierzą w to, co proponujemy. Kiedy zaczynałem uczyć, nawet moi tancerze często mówili, że wszystko wymyślam po to, żeby było inaczej. Wielu wywędrowało w świat i kiedy dziś wracaja, zapewniaja, że widzieli sporo, ale czegoś takiego, co tworzy Śląski Teatr Tańca, nie ma nigdzie" ${ }^{\prime 50}$.

\section{ZAKOŃCZENIE}

Śląski Teatr Tańca rozpoczą w latach dziewięćdziesiątych XX w. boom na teatry tańca w Polsce. Dzięki odwadze i determinacji J. Łumiński powołał do życia w 1991 r. pierwszy zawodowy zespół tańca współczesnego, który bardzo szybko zajął wiodąca pozycję w polskim środowisku tanecznym. Jego znaczenie wzrosło także dzięki umiejętnościom J. Łumińskiego w zakresie zarządzania i zagranicznej promocji. Śląski Teatr Tańca współpracuje również z wieloma krajowymi oraz zagranicznymi organizacjami i instytucjami, które wspomagaja jego działalność artystyczną i społeczną. Swoją pozycję teatr zawdzięcza także szeroko prowadzonej działalności edukacyjnej. Od początku lat dziewięćdziesiątych XX w. ogromne znaczenie edukacyjne miały ogólnopolskie i międzynarodowe warsztaty taneczne organizowane przez Śląski Teatr Tańca, na których kształciła się nowa generacja polskich tancerzy i choreografów oraz przygotowywano odpowiednio wyszkoloną kadrę nauczycielską. Jednak największym pragnieniem J. Łumińskiego było utworzenie od podstaw pierwszej w Polsce szkoły kształcącej tancerzy tańca współczesnego na poziomie uniwersyteckim. Po dwóch dekadach kształcenia kolejnych pokoleń tancerzy na licznych warsztatach, w końcu powstała specjalizacja ",aktor teatru tańca" w krakowskiej Państwowej Wyższej Szkole Teatralnej im. L. Solskiego w roku akademickim 2007/2008. Jest ona efektem koncepcji edukacyjnej J. Łumińskiego, w oparciu o długoletnie doświadczenie organizowania warsztatów tanecznych. Już wkrótce (2011/2012) opuszczą Szkołę pierwsi absolwenci Wydziału Teatru Tańca w Bytomiu.

Śląski Teatr Tańca słynie również z dbałości o doskonałą technikę tańca. To właśnie J. Łumiński stworzył swoją metodę tańca, która opiera się na balansowaniu pomiędzy skrajnościami. Tancerz usytuowany jest między podłogą a strzelistymi konstrukcjami scenografii. Wyeksponowuje to dramatyczność tańca i jednocześnie tworzy napięcie. Dynamiczne zwroty kierunków, nieoczekiwane upadki, policentryzm impulsów, skupianie i rozpraszanie energii, to podstawowe elementy metody J. Łumińskiego. Jego sposób pracy twórczej został doceniony zarówno w kraju, jak i zagranica. W swoich spektaklach z powodzeniem łączy nowoczesne formy choreograficzne z taneczną i muzyczną spuścizną polskiego folkloru oraz z tradycją żydowską. Mimo iż obecne choreografie twórcy Śląskiego Teatru Tańca nie są już tak nowatorskie w warstwie kompozycyjnej i ruchowej, to powstanie przy teatrze Laboratorium Choreograficznego daje nadzieję, na ożywienie i twórcze odrodzenie zespołu.

Bez wątpienia, dzisiejsza panorama tańca współczesnego w Polsce wyglądałaby całkowicie inaczej, gdyby nie działalność J. Łumińskiego i jego Śląskiego Teatru Tańca. Wywarł on ogromny wpływ na całe pokolenia tancerzy i choreografów oraz wytyczył nowe trendy taneczne. Na trwałe wpisał się w polską historię i rozwój tańca współczesnego końca XX w.

\footnotetext{
50 M. Skocza, dz. cyt.
} 


\section{Bibliografia}

(IS), Ale tańcza!!, „Gazeta Opolska”, 3-5.02.1995, nr 25.

Dąb A., Wierzę w cuda. Rozmowa z Jackiem Łumińskim, „,Gazeta Wyborcza”, 25.05.2001.

Goźliński P., Budzenie do tańca, „Na Przykład. Miesięcznik Kulturalny” 1998, nr 9.

Grabowska J., Szymajda J., Jacek Łumiński i Ślaski Teatr Tańca, [w:] tenże, Raport o tańcu wspótczesnym w Polsce w latach 19892009, Kraków - Łódź 2009.

Grabowska J., Szymajda J., Raport o tańcu wspótczesnym w Polsce w latach 1989-2009, Kraków-Łódź 2009.

Haponiuk M., ",Gazeta w Lublinie”, [w:] K. Furmaniuk, R. Kuśnierz, J. Łumiński (oprac.), Ślaski Teatr Tańca 1992-2002. Wydanie jubileuszowe Śląskiego Teatru Tańca, Bytom [2002].

Jarząbek D., Kościelniak M., Niziołek G. (red.), 20-lecie. Teatr polski po 1989, Kraków 2010.

Kamiński B., Taniec doświadczé́. Festiwal Sztuki Tanecznej w Bytomiu, „Życie”, 29.06.1998.

Katalog XII Międzynarodowej Konferencji Tańca Wspótczesnego i Festiwalu Sztuki Tanecznej, Śląski Teatr Tańca, Bytom 2005.

Katalog 17 Międzynarodowej Konferencji Tańca Wspótczesnego i Festiwalu Sztuki Tanecznej, Śląski Teatr Tańca, Bytom 2010.

Kisselgoff A., „The New York Thimes”, [w:] K. Furmaniuk, R. Kuśnierz, J. Łumiński (oprac.) Śląski Teatr Tańca 1992-2002. Wydanie jubileuszowe Śląskiego Teatru Tańca, Bytom [2002].

Królica A., Ciało tańczace poza cielesnościa, czyli o paradoksach polskiego tańca, [w:] D. Jarząbek, M. Kościelniak, G. Niziołek (red.), 20-lecie. Teatr polski po 1989, Kraków 2010.

Kucharski A. J., Cztery wymiary Ślaskiego Teatru Tańca, [w:] K. Furmaniuk, R. Kuśnierz, J. Łumiński (oprac.), Śląski Teatr Tańca 1992-2002. Wydanie jubileuszowe Śląskiego Teatru Tańca, Bytom [2002].

Leśnierowska J., Na czym polega fenomen Ślaskiego Teatru Tańca na polskiej scenie?, [w:] K. Furmaniuk, R. Kuśnierz, J. Łumiński (oprac.), Ślaski Teatr Tańca 1992-2002. Wydanie jubileuszowe Śląskiego Teatru Tańca, Bytom [2002].

Mrozek W., Raport o stanie tańca w wojezwództwie ślaskim, Instytut Muzyki i Tańca 2011.

Mrówka D., Skarb nieodnaleziony, ",Gazeta Wyborcza”, 6.06.2001.

Program Prosto w oczy, Śląski Teatr Tańca, Bytom 22.06.2003.

Skocza M., To, co najlepsze - nasze!, „Dziennik Zachodni", 7.07.1999.

Skoczyna M., Wedtug Eumińskiego, "Śląsk" 1997, nr 2 (16).

Ślaski Teatr Tańca 1992-2002. Wydanie jubileuszowe Śląskiego Teatru Tańca, Bytom [2002].

Wilk S., ,"Życie”, [w:] K. Furmaniuk, R. Kuśnierz, J. Łumiński (oprac.), Ślaski Teatr Tańca 1992-2002. Wydanie jubileuszowe Śląskiego Teatru Tańca, Bytom [2002].

\section{Netografia}

Hoczyk J., Bytom - zmierzch legendy, [w:] tejże, Teatr tańca AD 2008. Nadzieje $i$ kontynuacje, „Kultura Enter. Miesięcznik Wymiany Idei", http://kulturaenter.nazwa.pl/0/01t4.html, 12.04.2010.

Hoczyk J., Teatr tańca AD 2008. Nadzieje i kontynuacje, „Kultura Enter. Miesięcznik Wymiany Idei”, http://kulturaenter. nazwa.pl/0/01t4.html, 12.04.2010.

Lubina-Cipińska D., Sztuka i warsztaty. Rozmowa z Jackiem Łumińskim, „,Rzeczpospolita”, 29.04.2002, http://www.teatry. art.pl/!rozmowy/sztukai.htm, 26.09.2005.

Łumiński J., Taniec jest życiem. Magdalena Podziewska rozmawia z Jackiem Łumińskim, „Ultramaryna”, czerwiec 2011, http://www.ultramaryna.pl/tekst.php?id=907, 15.11.2011.

Mikurt M., ,Fabryka Tańca”, http://www.stt.art.pl/pl_pl/spektakle_11_12/la_la_land.html, 20.11.2011.

Misiewicz A., ,"Gazeta Wyborcza”, http://www.stt.art.pl/pl_pl/spektakle_11_12/la_la_land.html, 20.11.2011.

Skocza M., Metoda Łumińskiego. Wywiad z J. Łumińskim, "Śląsk” nr 2, 10.03.2011 r., http://www.teatry.art.pl/n/czytaj/27531, 20.11.2011.

http://www.kongrestanca.pl/pl/materialy, 22.04.2011.

http://www.kongrestanca.pl/uploads/files/11_raport-slask-pdf.pdf, 22.04.2011.

http://www.pwst.krakow.pl/?strona=2\&lp=3, 15.10.2011.

http://www.stt.art.pl, 20.11.2011.

http://www.stt.art.pl/pl_pl/o_teatrze/jacek_luminski.html, 15.10.2011.

http://www.stt.art.pl/pl_pl/o_teatrze/nota.html, 15.10.2011.

http://www.stt.art.pl/pl_pl/o_teatrze/organizacja.html, 15.10.2011.

\section{STRESZCZENIE}

Lata dziewięćdziesiąte XX w. były dla rozwoju polskiego tańca współczesnego okresem przełomowym. W 1991 r. Jacek Łumiński zakłada Śląski Teatr Tańca w Bytomiu, który stano- 
wi bez wątpienia awangardę wszelkich działań w rozwoju tańca współczesnego w Polsce. To właśnie Śląski Teatr Tańca J. Łumińskiego na początku lat dziewięćdziesiątych XX w. wytyczył nowe trendy w tańcu współczesnym, prowadząc jednocześnie, przez ostatnie dwadzieścia lat, działalność edukacyjną.

Niniejszy artykuł przedstawia działalność artystyczno-edukacyjną Śląskiego Teatru Tańca na przestrzeni ostatnich dwudziestu lat. Na wstępie autorka nakreśla choreograficzny portret J. Łumińskiego, założyciela i choreografa Śląskiego Teatru Tańca, twórcy polskiej techniki tańca współczesnego. Następnie dokonuje analizy stylu tańca wykreowanego przez J. Łumińskiego oraz przeglądu dorobku choreograficznego Śląskiego Teatru Tańca.

W zakończeniu omawia szeroką panoramę działań edukacyjnych podjętych przez Ślacki Teatr Tańca w dziedzinie profesjonalnego tańca współczesnego oraz fenomen tego teatru na scenie polskiej.

Słowa kluczowe: Jacek Łumiński, Śląski Teatr Tańca, taniec współczesny, historia tańca w Polsce - XX w., edukacja taneczna.

\section{Straight in the Eyes: Jacek Łumiński and the Silesian Dance Theatre (1991-2011)}

\section{Summary}

The last decade of the 20th century marked a turning-point in the development of Polish contemporary dance. In 1991, Jacek Luminski established the Silesian Dance Theatre in Bytom. The theatre is said to have been the avant-garde of all activities around contemporary dance in Poland. It was J. Luminski and his theatre that set new trends in contemporary dance of the early 1990s, at the same time having fulfilled educational purposes for the last twenty years.

The aim of this article is to present the artistic and educational activity of the Silesian Dance Theatre of the last twenty years. It first presents a choreographic portrait of J. Luminski, founder and choreographer of the Silesian Dance Theatre, the creator of the Polish contemporary dance technique. Then, this paper analyses Luminski's dance style and reviews the Silesian Dance Theatre's choreographic achievements.

The final part of the article discusses a wide spectrum of educational activities undertaken in the field of contemporary professional dance by the Silesian Dance Theatre, and the phenomenon of theatre on the Polish stage.

Key words: Jacek Luminski, Silesian Dance Theatre, contemporary dance, history of dance in Poland - $20^{\text {th }}$ century, dance education. 